\title{
Comparing international approaches to food safety regulation of GM and Novel Foods
}

Area of research interest: Novel and non-traditional foods, additives and processes

Study duration: 2020-06-01

Project status: Completed

Project code: FS304005

Conducted by: Campden BRI (Chipping Campden) Ltd

Date published: 10 August 2021

DOI: https://doi.org/10.46756/sci.fsa.rdg239

\section{Background}

The global area of genetically modified (GM) crop production has increased considerably over the past two decades. In 2015 , GM crops were found to be cultivated in about 28 countries, accounting for over $10 \%$ of the world's fertile land.

A 'novel food' is any food or substance that has not been used for human consumption to a significant degree within the EU before 15 May 1997. Since then, there has been over 90 novel foods authorisations approved for use by the EU.

There is a variation around the world in how novel foods and genetically modified organisms (GMOs) are regulated. Many countries have specifically developed their own regulatory frameworks to control the placement of such products on their markets.

\section{Research approach}

A qualitative assessment was carried out on how the regulation of novel foods and GMOs in selected non-EU countries differs from those current requirements in the United Kingdom. Countries of interest for novel foods that were selected for review included Australia, Canada, Japan, and the United States. The review focused ontheir approach to 'novelty' determination, authorisation processes, differences in terminology, safety standards, and evidence-based requirements. In reviewing the regulatory approaches for GMOs, the countries selected were Argentina, Australia, Brazil, Canada, and the United States, as best representing key differences.

Systems were also identified which regulate the international trade of such commodities, by considering relevant treaties that operate at a global level. These systems included the General Agreement on Tariffs and Trade (GATT), the World Trade Organisation (WTO) Agreement on the Application of Sanitary and Phytosanitary Measures (SPS Agreement), and the WTO Agreement on Technical Barriers to Trade (TBT Agreement). Elements of free trade agreements between the signatories of two or more jurisdictions were also considered in this report.

\section{Research report}

PDF

View Comparing international approaches to food safety regulation of GM and Novel Foods as PDF(Open in a new window) (1.55 MB) 